\title{
In vitro virulence characteristics of rare serovars of Salmonella enterica isolated from sand lizards (Lacerta agilis L.)
}

\author{
Joanna Mokracka - Sylwia Krzymińska - Danił Ałtunin - Dariusz Wasyl • \\ Ryszard Koczura - Krzysztof Dudek • Monika Dudek • Zofia Anna Chyleńska • \\ Anna Ekner-Grzyb
}

Received: 29 January 2018/Accepted: 31 March 2018/Published online: 19 May 2018

(C) The Author(s) 2018

\begin{abstract}
The aim of this study was to estimate virulence potential of Salmonella enterica strains colonizing the gut of free-living sand lizards (Lacerta agilis L.). The strains belonged to three Salmonella serovars: Abony, Schleissheim, and Telhashomer. Adhesion and invasion abilities of the strains were determined in quantitative assays using the gentamicin protection method. Induction of apoptosis was assessed using HeLa cell monolayers. PCR assays
\end{abstract}

Electronic supplementary material The online version of this article (https://doi.org/10.1007/s10482-018-1079-8) contains supplementary material, which is available to authorized users.

J. Mokracka $(\bowtie) \cdot$ S. Krzymińska · D. Ałtunin ·

R. Koczura

Department of Microbiology, Faculty of Biology, Adam

Mickiewicz University in Poznań, Umultowska 89,

61-614 Poznan, Poland

e-mail: amok@amu.edu.pl

D. Wasyl

Department of Microbiology, National Veterinary

Research Institute, Partyzantów 57, 24-100 Puławy, Poland

K. Dudek

Department of Zoology, Institute of Zoology, Poznań University of Life Sciences, Wojska Polskiego 71 C, 60-625 Poznan, Poland

M. Dudek

Laboratory of Neurobiology, Institute of Zoology, Poznań University of Life Sciences, Wojska Polskiego 71 C, 60-625 Poznan, Poland were used for detection of 26 virulence genes localised within mobile elements: pathogenicity islands, virulence plasmids, and prophage sequences. In vitro studies revealed that all strains had adhesion and invasion abilities to human epithelial cells. The isolates were cytotoxic and induced apoptosis of the cells. The serovars differed in the number of virulence-associated genes: up to 18 genes were present in Salmonella Schleissheim, 17 in Salmonella Abony, whereas as few as six genes were found in Salmonella Telhashomer. Generally, Salmonella Abony and Salmonella Schleissheim did not differ much in gene content connected with the presence SPI-1 to -5. All of

\footnotetext{
Z. A. Chyleńska

Department of Nature Education and Conservation, Faculty of Biology, Adam Mickiewicz University in Poznań, Umultowska 89, 61-614 Poznan, Poland

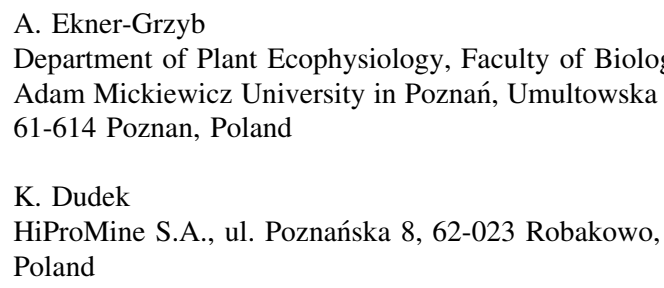


the strains lacked genes localised within bacteriophages and plasmids. The presence of virulenceassociated genes and in vitro pathogenicity assays suggest that Salmonella sp. strains originating from autochthonous, free-living lizards can potentially infect and cause disease in humans.

Keywords Pathogenicity islands - Reptile · Salmonellosis · Virulence · Wildlife

\section{Introduction}

The natural habitat of Salmonella enterica is the intestine of warm-blooded and many cold-blooded vertebrates. S. enterica is divided into six subspecies: enterica, salamae, arizonae, diarizonae, houtenae, and indica. Strains belonging to $S$. enterica subsp. enterica cause approximately $99 \%$ of Salmonella sp. infections in humans and warm-blooded animals, resulting in manifestations ranging from asymptomatic carriage to systemic disease (Hoelzer et al. 2011; Gal-Mor et al. 2014). Invasive, extraintestinal disease can lead to bacteraemia and systemic infections, especially in immunocompromised patients. S. enterica subsp. enterica comprises as many as 1586 serovars (Issenhuth-Jeanjean et al. 2014) including a few host-adapted to humans and some primates (i.e. S. Typhi and $S$. Paratyphi) or specific mammals or avian species (i.e. pig-associated $S$. Choleraesuis and fowl pathogen $S$. Gallinarum). However, a vast majority of others, such as $S$. Typhimurium and $S$. Enteritidis, tend to cause gastroenteritis in many different host species (Uzzau et al. 2000; Boyle et al. 2007).

The mechanism of S. enterica serovars pathogenicity is still unclear. Most virulence genes associated with bacterial adhesion, invasion, intravacuolar survival and extraintestinal spread are located within Salmonella pathogenicity islands (SPIs), plasmids and phages. To date, there have been 28 Salmonella pathogenicity islands detected (Yoon et al. 2015), of which 21 are characterised (Uzzau et al. 2000; Sabbagh et al. 2010). Experiments with animal models using host-specific Salmonella sp. have revealed that SPIs play a major role in host range and pathology of infection (Marcus et al. 2000). It has been suggested that a combination of virulence factors specific to each serovar, encoded by SPIs and virulence plasmids, is involved in the severity of salmonellosis (Andino and Hanning 2015).
Reptiles represent an important reservoir of salmonellae in nature (Geue and Löschner 2002; Briones et al. 2004) and have potential implications for public health. Although homeothermic animals and humans can contract salmonellosis from reptiles, most Salmonella serovars encountered in those animals have been rarely isolated from mammals and birds (Bäumler et al. 1996; Pasmans et al. 2005; Hoelzer et al. 2011).

The aim of this study was to estimate adhesion and invasion abilities to human epithelial cells, as well as cytotoxic and apoptotic activities, of Salmonella strains originating from sand lizards (Lacerta agilis L.), and to determine the presence of virulenceassociated genes in their genomes.

\section{Materials and methods}

\section{Bacterial strains}

Eight genetically unrelated Salmonella strains cultured from faecal samples of free-living sand lizards Lacerta agilis L. (Dudek et al. 2016) were used in the study (Table 1). They were isolated in RappaportVassiliadis medium and Brilliant Green Agar, and identified as $S$. enterica subsp. enterica serovar Schleissheim $(\mathrm{n}=5), S$. Abony $(\mathrm{n}=2)$ and $S$. Telhashomer $(\mathrm{n}=1)$, according to EN ISO 6579:2002/ A1:2007 and the presence of the invA gene (Zajac et al. 2016).

Cultivation and infection of human epithelial cells

Human epithelial cells originated from cervical cancer HeLa cell line. They were cultivated in growth medium (GM) with RPMI (Gibco), supplemented with heat-inactivated $5 \%$ fetal calf serum (FCS, Gibco), streptomycin $\left(100 \mu \mathrm{g} \mathrm{ml}^{-1}\right)$, penicillin (100 $\mathrm{U} \mathrm{ml}^{-1}$ ) and $2 \mathrm{mM}$ L-glutamine, Gibco). The cells $\left(1 \times 10^{5} \mathrm{ml}^{-1}\right)$ were seeded into 96 -well plates (Greiner Bio-One) and incubation was carried out at $37{ }^{\circ} \mathrm{C}$ in humidified atmosphere with $5 \% \quad \mathrm{CO}_{2}$ (Nawrot et al. 2010).

Monolayers of HeLa cells were infected with Salmonella spp. isolates at multiplicity of infection (MOI) of 1:100 for $90 \mathrm{~min}$ (Suez et al. 2013). The cells were washed three times with phosphate buffered saline (PBS, Biomed) for assessment of bacterial 
Table 1 Virulenceassociated genes of $S$. enterica strains isolated from wild lizards
${ }^{\mathrm{a}} T$. Telhashomer

${ }^{\mathrm{b}}$ Indicates presence of a gene

\begin{tabular}{|c|c|c|c|c|c|c|c|c|c|}
\hline \multirow[t]{3}{*}{ Gene } & \multirow[t]{3}{*}{ Location } & \multicolumn{8}{|c|}{ Salmonella serovar and strain ID } \\
\hline & & \multicolumn{5}{|c|}{ Schleissheim } & \multicolumn{2}{|c|}{ Abony } & \multirow{2}{*}{$\begin{array}{l}\mathrm{T}^{\mathrm{a}} \\
\mathrm{J} 10\end{array}$} \\
\hline & & $\mathrm{J} 1$ & J6 & $\mathrm{J} 7$ & $\mathrm{~J} 33$ & $\mathrm{~J} 36$ & $\mathrm{~J} 23$ & $\mathrm{~J} 27$ & \\
\hline avrA & SPI-1 & & $\diamond^{\mathrm{b}}$ & $\diamond$ & & $\diamond$ & $\bullet$ & $\diamond$ & \\
\hline $\operatorname{invA}$ & & $\diamond$ & $\diamond$ & $\diamond$ & $\diamond$ & $\diamond$ & $\diamond$ & $\diamond$ & $\diamond$ \\
\hline $\operatorname{org} A$ & & $\diamond$ & $\diamond$ & $\diamond$ & $\diamond$ & $\diamond$ & $\diamond$ & $\diamond$ & \\
\hline $\operatorname{prgH}$ & & $\diamond$ & $\bullet$ & $\bullet$ & $\bullet$ & $\diamond$ & $\diamond$ & $\diamond$ & \\
\hline $\operatorname{sip} B$ & & $\diamond$ & $\bullet$ & $\diamond$ & $\bullet$ & $\bullet$ & $\diamond$ & $\bullet$ & \\
\hline $\operatorname{spaN}$ & & $\diamond$ & $\bullet$ & $\bullet$ & $\diamond$ & $\diamond$ & $\diamond$ & $\diamond$ & \\
\hline $\operatorname{ssa} Q$ & SPI-2 & $\diamond$ & $\bullet$ & $\diamond$ & $\bullet$ & $\diamond$ & $\diamond$ & $\bullet$ & $\diamond$ \\
\hline spiA & & $\diamond$ & $\diamond$ & $\diamond$ & $\diamond$ & $\diamond$ & $\diamond$ & $\diamond$ & \\
\hline$m g t C$ & SPI-3 & $\diamond$ & $\diamond$ & $\diamond$ & $\diamond$ & $\diamond$ & $\diamond$ & $\diamond$ & $\diamond$ \\
\hline $\operatorname{siiD}$ & SPI-4 & $\diamond$ & $\diamond$ & $\diamond$ & $\diamond$ & $\diamond$ & $\diamond$ & $\diamond$ & $\diamond$ \\
\hline $\operatorname{sop} B$ & SPI-5 & $\diamond$ & $\diamond$ & $\diamond$ & $\diamond$ & $\diamond$ & $\diamond$ & $\bullet$ & $\diamond$ \\
\hline sopE & SPI 7/MPI & $\diamond$ & $\diamond$ & $\diamond$ & $\diamond$ & $\diamond$ & $\diamond$ & $\diamond$ & \\
\hline$m s g A$ & SPI-11 & $\diamond$ & $\diamond$ & $\bullet$ & $\bullet$ & $\diamond$ & $\bullet$ & $\diamond$ & $\diamond$ \\
\hline pagC & SPI-11 & $\diamond$ & $\diamond$ & $\diamond$ & $\diamond$ & $\diamond$ & $\diamond$ & $\diamond$ & \\
\hline$c d t B$ & cdtB islet/SPI11 & & & & & & & & \\
\hline $\operatorname{lpfC}$ & Pathogenicity islet & & & & & & & & \\
\hline sifA & Pathogenicity islet & $\diamond$ & $\bullet$ & $\diamond$ & $\diamond$ & $\diamond$ & $\diamond$ & $\diamond$ & \\
\hline sodC1 & Gifsy2 & & & & & & & & \\
\hline gipA & Gifsyl & $\diamond$ & $\bullet$ & $\diamond$ & $\diamond$ & $\diamond$ & & & \\
\hline$b c f C$ & $33 \mathrm{~kb}$ island & & & & & & & & \\
\hline $\operatorname{spv} C$ & Virulence plasmid & & & & & & & & \\
\hline pefA & Virulence plasmid & & & & & & & & \\
\hline tolC & Chromosome & $\diamond$ & $\diamond$ & $\bullet$ & $\bullet$ & $\diamond$ & $\bullet$ & $\diamond$ & \\
\hline fyuA & HPI & & & & & & & & \\
\hline$i u t A$ & Plasmid IncFIB & & & & & & & & \\
\hline iroN & Chromosome & $\diamond$ & $\diamond$ & $\diamond$ & $\diamond$ & $\diamond$ & $\diamond$ & $\diamond$ & $\diamond$ \\
\hline
\end{tabular}

non-pathogenic Escherichia coli K12C600 were included.

Cytotoxic activity of extracellular factors

Activity of cytotoxic virulence factors was analysed in bacterial filtrates. Overnight bacterial cultures in Tryptic Soy Broth (TSB, Difco) were incubated in the medium at $37{ }^{\circ} \mathrm{C}$ for $18 \mathrm{~h}$ with agitation at $300 \mathrm{rpm}$ (Krzymińska et al. 2010; Cooley et al. 2014). The supernatants were centrifuged at $3000 \times g$ for $20 \mathrm{~min}$ and sterilised through $0.22 \mu \mathrm{m}$ pore size membrane filters Millex-GV (Millipore). Confluent monolayers of HeLa cells were incubated with culture filtrates of Salmonella spp. and nonpathogenic E. coli K-12 C600 for $24 \mathrm{~h}$ at $37{ }^{\circ} \mathrm{C}$. 
Cytotoxic activity to human epithelial cells was observed under an inverted microscope.

\section{Assessment of apoptosis}

Monolayers were detached using $0.25 \%$ trypsin and $0.25 \%$ EDTA in PBS. Cell suspensions were stained with Acridine Orange $\left(100 \mu \mathrm{g} \mathrm{ml}^{-1}\right)$ and Ethidium Bromide (100 $\mu \mathrm{g} \mathrm{ml}^{-1}$ ) solution, and examined under the fluorescence microscope (Nikon Eclipse TE2000). The percentage of apoptotic cells were expressed as apoptotic index (ApI) and presented as means (standard deviation) from two experiments performed in triplicate. In positive controls, the HeLa cell monolayers were UV-B-irradiated $\left(180 \mathrm{~J} \mathrm{~m}^{-2}\right)$, whereas the cells incubated in GM comprised negative control (Ribble et al. 2005).

Siderophore production

Cross-feeding assays with indicator strains $S$. Typhimurium TA 2700 (enterobactin and other catecholate siderophores indicator), E. coli LG 1522 (aerobactin and rhodotorulic acid indicator) and Yersinia enterocolitica 5030 (yersiniabactin indicator) were used for determination of siderophore production (Reissbrodt and Rabsch 1988; Haag et al. 1993).

Identification of virulence genes

Virulence genes characteristic for Salmonella spp. were detected by PCR assays. The targeted genes encode products associated with cellular invasion (avrA, invA, orgA, prgH, sipB, spaN, sopB, sopE1, gipA, $c d t B, t o l C)$, survival within a cell (ssaQ, sifA, pagC, spvC, spiA, mgtC, sodC1, msgA), and adhesin or pili production ( $s i i D, l p f C$, pefA, $b c f C$ ). The remaining genes are associated with iron acquisition (iroN, iutA and $f y u A$ ) (Supplementary Table 1). The PCR conditions and primer sequences have been published elsewhere (Schubert et al. 1998; Skyberg et al. 2006; Huehn et al. 2010).

\section{Results and discussion}

In this study, we characterised virulence potential of eight Salmonella strains isolated from autochthonous sand lizards living in natural environments in an urbanised area. The first step of bacterial colonization of host epithelium and establishment of infection is adhesion of the pathogen to the cells (López et al. 2012). All strains demonstrated the ability to adhere to human epithelial cells (Table 2). The adhesion indexes of the strains ranged from $4.7 \times 10^{5}$ for $S$. Telhashomer J10 to $7.9 \times 10^{8} \mathrm{CFU}$ for $S$. Schleissheim J36. The indexes were higher than those of nonpathogenic E. coli $\mathrm{K} 12 \mathrm{C} 600\left(0.12 \times 10^{3}\right)$, and positive control $S$. Typhimurium ATCC 13311 $\left(7.8 \times 10^{4} \mathrm{CFU}\right)$. Several bacterial factors are involved in interactions with host receptors. López et al. (2012) have suggested that $S$. Typhimurium produce at least 13 fimbrial and three nonfimbrial adhesins. In a recent study, S. enterica isolates could produce adhesins including lipopolysaccharide (LPS) and SiiD protein that is recognised by Toll-like receptors.

All Salmonella tested were invasive to HeLa cells. Invasion indices ranged from $1 \times 10^{4}(\mathrm{~S}$. Schleissheim $\mathrm{J} 1)$ to $23.7 \times 10^{6}(S$. Abony $\mathrm{J} 23)$ and $17.8 \times 10^{6}(S$. Schleissheim J36) (Table 2). The index of $S$. Typhimurium ATCC 13311 was $8.7 \times 10^{5}$. Non-pathogenic E. coli K12C600 was not invasive to HeLa cells. In epithelial cells Salmonella spp. strains are enclosed within vacuoles. To establish invasion to host cells, the bacteria use products of at least 29 genes located on SPI-1 (López et al. 2012). On the basis of the presence of selected virulence genes, we observed that $S$. enterica could probably invade nonphagocytic human cells by a "trigger" mechanism. The strains likely use T3SS-1 to inject the products of $\operatorname{sip} A$, invA, $\operatorname{sop} B$, and $\operatorname{sii}$ genes into epithelial cells. Those genes were observed in both $S$. Schleissheim and $S$. Abony. SipA effector binds directly to actin, whereas SopB activates RhoGTPases, which trigger cellular proteins that cause depolymerisation of actin. The rearrangement of the host cytoskeleton drives bacterial entry (Velge et al. 2012). SipA, SopB and InvA effector proteins could also activate signal transduction cascades, leading to chemotaxis of leucocytes and synthesis of pro-inflammatory cytokines (López et al. 2012).

All tested Salmonella cell-free supernatants displayed cytotoxic activity to human epithelial cells, seen as destruction of infected HeLa cells. The results suggest that the strains produced extracellular cytotoxic factors. Wang et al. (2013) have reported Salmonella strains producing AB5 toxins which cause 
Table 2 Adhesion, invasion and apoptosis indexes of $S$. enterica strains isolated from wild lizards

\begin{tabular}{|c|c|c|c|c|c|c|c|c|}
\hline \multirow[t]{3}{*}{ Index } & \multicolumn{8}{|c|}{ Salmonella serovar and strain ID } \\
\hline & \multicolumn{5}{|c|}{ Schleissheim } & \multicolumn{2}{|l|}{ Abony } & \multirow{2}{*}{$\begin{array}{l}\mathrm{T}^{*} \\
\mathrm{~J} 10\end{array}$} \\
\hline & $\mathrm{J} 1$ & J6 & $\mathrm{J} 7$ & $\mathrm{~J} 33$ & $\mathrm{~J} 36$ & $\mathrm{~J} 23$ & $\mathrm{~J} 27$ & \\
\hline $\begin{array}{l}\text { Adhesion index } \\
\left(\times 10^{6}\right)\end{array}$ & $\begin{array}{l}1.03 \\
(0.56)^{\mathrm{a}}\end{array}$ & $\begin{array}{l}5.67 \\
(2.41)\end{array}$ & $\begin{array}{l}0.69 \\
\quad(0.27)\end{array}$ & $\begin{array}{l}48.5 \\
\quad(10.80)\end{array}$ & $\begin{array}{l}795.0 \\
(257.30)\end{array}$ & $\begin{array}{l}44.81 \\
\quad(21.17)\end{array}$ & $\begin{array}{l}2.53 \\
(1.28)\end{array}$ & $\begin{array}{l}0.47 \\
\quad(0.17)\end{array}$ \\
\hline $\begin{array}{l}\text { Invasion index } \\
\left(\times 10^{6}\right)\end{array}$ & $\begin{array}{l}0.01 \\
\quad(0.00)^{\mathrm{b}}\end{array}$ & $\begin{array}{l}3.21 \\
(1.22)\end{array}$ & $\begin{array}{l}0.18 \\
\quad(0.06)\end{array}$ & $0.38(0.17)$ & $17.82(6.82)$ & $\begin{array}{l}23.74 \\
(14.37)\end{array}$ & $\begin{array}{l}1.97 \\
(0.69)\end{array}$ & $\begin{array}{l}0.12 \\
\quad(0.04)\end{array}$ \\
\hline Apoptosis index $(\%)$ & $38.7(9.6)^{\mathrm{c}}$ & $\begin{array}{l}32.3 \\
(11.4)\end{array}$ & $15.6(4.1)$ & $31.2(18.2)$ & $63.4(21.6)$ & $79.5(12.7)$ & $29.1(7.2)$ & $4.1(2.7)$ \\
\hline
\end{tabular}

*Telhashomer

${ }^{\mathrm{a}}$ The number of associated $(\mathrm{CFU})$ bacteria/ $1 \times 10^{5} \mathrm{HeLa}$ cells

${ }^{\mathrm{b}}$ The number of internalized bacteria/ $1 \times 10^{5}$ HeLa cells

${ }^{\mathrm{c}}$ The percentage of apoptotic cells. All index values are presented as means (standard deviation) from two experiments performed in triplicate

signalling responses that result in secretion of proinflammatory cytokines and chemokines produced by human macrophages, epithelial and endothelial cells. The toxins consist of catalytic A- and pentameric B- subunits (Beddoe et al. 2010). Rytkönen et al. (2007) suggested that cytotoxic activity of Salmonella depends on the SseL effector, translocation of which is related to the SPI-2 type III secretion system. The protein SseL is similar to cysteine proteases with deubiquitinating activity.

All Salmonella were able to induce human epithelial cell death (Table 2). After Ethidium Bromide/ Acridine Orange staining, live cells appeared green, whereas late-stage apoptotic cells are shown with orange fragmented nuclei (Supplementary Fig. 1). The highest apoptotic index was noted in cells infected with $S$. Abony J23 (79.5\%) and $S$. Schleissheim J36 (63.4\%), whilst the lowest was in the case of $S$. Telhashomer $(4.1 \%)$. The mechanism of apoptosis involves SPI-1 effectors (López et al. 2012). Most of the analysed strains harboured SPI-1-located $\operatorname{sip} B$ encoding an effector protein that causes activation of caspase-1.

Pathogenicity of Salmonella is associated with the presence of virulence-related genes encoding proteins involved in colonization and survival within hosts (Huehn et al. 2010). The selected 26 virulence genes are located within mobile elements: pathogenicity islands, virulence plasmids, and prophage sequences (Table 1). The strains differed in the number of virulence-associated genes: up to 18 and 17 were present in $S$. Schleissheim and $S$. Abony, respectively, whereas only seven genes were noted in $S$. Telhashomer. Those seven genes (invA, ssaQ, mgtC, siiD, sop $B, m s g A$, iroN) were present in all tested strains (Table 1).

Genes localised in SPI-1 and SPI-2, namely $\operatorname{sip} B$, invA, $\operatorname{prg} H, \operatorname{spaN}, \operatorname{org} A, \operatorname{ssa} Q$, and spiA was present in all $S$. Schleissheim and Abony strains; whereas avrA in all but two strains of $S$. Schleissheim. None of the SPI1 genes was found in $S$. Telhashomer, which may indicate the absence of the island resulting in the lowest adhesion and apoptotic indexes. SPI-1 and SPI2 genes are necessary for colonization and invasion to epithelial cells. The lack of avrA in two $S$. Schleissheim may be a result of recombination which often takes place in that locus (Borges et al. 2013). Moreover, in $S$. Typhi and $S$. Paratyphi, the lack of avrA is coincident with the ability of these strains to avoid immunological responses in the intestine, which leads to systemic infection (Prager et al. 2000). Besides, in S. enterica, even if present, avrA often did not express AvrA protein (Streckel et al. 2004). The $s s a Q$ and spiA genes coding for proteins of the SPI-2 type III secretion system are essential for virulence in host cells, survival within macrophages, and biofilm formation (Dong et al. 2011).

The $m g t C$ gene located within SPI-3, siiD within SPI-4 and sopB in SPI-5 were present in strains of all the three serovars. The $m g t B C$ operon is necessary for inducing systemic infection in mice, SiiD secretion protein is associated with T1SS and $\operatorname{sop} B$-encoded 
inositol phosphatase is involved in triggering fluid secretion secreted via SPI-1 encoded T3SS (Morgan et al. 2007).

Animal models using host-specific Salmonella sp. have shown that SPIs play crucial roles in host range and pathology of infection. SPI-1 and SPI-5 encode proteins appearing to have their virulence function restricted to the gut, whereas those of SPI-2, SPI-3, SPI-4 and the virulence plasmid seem to have adapted Salmonella spp. for growth in macrophages (Marcus et al. 2000). However, it has been reported that SPI-1encoded SipB, SipC and SipD proteins have impact also on long-term systemic infection in mice (Lawley et al. 2006). Similarly, the AvrA efector protein is synthesized in $S$. Enteritidis not only in the intestine but also in systemic infection and may be secreted by T3SS 1 and 2 (Giacomodonato et al. 2014).

The $m s g A$ and $p a g C$ genes located within SPI-11, promoting survival within macrophages, were present in all isolates except for pagC absent in $S$. Telhasomer. SPI-11 has a mosaic structure and therefore its parts can be present or absent in genomes of $S$. Typhimurium and $S$. Typhi strains (Morgan 2007).

Generally, we noticed that strains of serovars Abony and Schleissheim did not differ in gene content connected with SPI-1 to -5 and pagC (SPI-11) presence. Suez et al. (2013) analysed virulence gene profiles of invasive non-typhoidal Salmonella and allocated genes of SPI-1-5, -9, -13, -14 to the core part of the genomes.

The tolC, sifA, and gipA genes were present in all $S$. Schleissheim strains and sifA and tolC in S. Abony. The sifA gene has been encountered among genes usually absent from invasive non-typhoidal Salmonella serovars and required probably for adaptation of some serovars to a specific homoeothermic hosts (Suez et al. 2013). Apart from siderophore receptor genes iutA and $f y u A$, five genes were absent in all

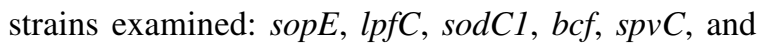
pefA. Absence of a virulence gene may suggest that it is not essential for invasive manifestation in humans as was suggested for the lack of sopE located within SopE $\varphi$ on SPI-7, encoding effector protein for SPI-1 $\mathrm{T} 3 \mathrm{SS}$, in the case of $80 \%$ invasive non-typhoidal strains originated from human blood (Suez et al. 2013). On the other hand the gene was noted in all $S$. Enteritidis strains isolated from broiler meat and slaughterhouse (Borges et al. 2013), whereas sopE was demonstrated only in $24 \%$ of genomes of Salmonella isolated from captive lizards (Pasmans et al. 2005).
Plasmid-mediated pefA and $s p v C$ genes were absent from isolates of all three serovars, suggesting that they can be encoded by the same virulence plasmid (Skyberg et al. 2006). In mammals and birds, the $s p v$ virulence locus is required for sustained extra-intestinal infections and clinical disease through macrophage cytotoxicity, and destabilisation of the cytoskeleton of the eukaryotic cells. In strains isolated from captive lizards, it has been present in a single Salmonella strain, which coincided with the limited number of extra-intestinal infections in lizards and seems not to be crucial for sustained colonization (Pasmans et al. 2005).

In the genomes of $S$. Schleissheim and $S$. Abony, we found typhoid-associated virulence gene $c d t B$. The presence of $c d t B$ has been primarily related to human Salmonella isolates (Haghjoo and Galan 2004). However, Skyberg et al. (2006) have reported the gene in Salmonella mainly associated with avian salmonellosis and isolated from healthy birds.

All Salmonella serovars produced a catecholate siderophore and had a receptor gene (iroN) for salmochelin, which is glycosylated enterobactin. Salmochelin is not susceptible to lipocalin-2, a protein preventing bacterial iron acquisition. Lipocalin-2 resistance mediated by iroN confers a specific benefit during growth of $S$. Typhimurium in inflamed cecum of mice (Raffatellu et al. 2009).

$S$. Abony, Schleissheim and Telhashomer are not often encountered in mammals and birds (Bäumler et al. 1996; Uzzau et al. 2000). S. Abony was detected with $6.2 \%$ frequency in Mediterranean turtle Testudo graeca faeces (Briones et al. 2004) and it was occasionally associated with human salmonellosis (Hall and Rowe 1992; Woodward et al. 1997). S. Schleissheim was identified in cattle (Wieczorek and Osek 2013) and mistle thrush Turdus viscivorus (Hernandez et al. 2003). Human salmonellosis caused by this serovar has been previously reported in Turkey (Aksoycan et al. 1983) and Poland (PZH and GIS 2016). Both serovars occur occasionally in Poland in wildlife and food-producing animals, as well as organic fertilizers (Skarżyńska et al. 2017). S. Telhashomer has been identified more frequently than other serovars in toads (Sharma et al. 1977), but no reports of human cases was noted. In human-influenced environments, Salmonella spp. found in wild animals might coincide with serovars disseminated to the habitat (Palmgren et al. 2000). 
The results of this study showed that free-living sand lizards occurring in common urban locations can be carriers of pathogenic Salmonella, as the strains revealed adhesion, invasion, cytotoxicity and induced apoptosis of human epithelial cells, although the serovars Schleissheim, Abony and Telhashomer differed in their virulence gene profiles. They may pose a disease threat if the bacterium is transferred from clinically healthy native reptiles into birds, mammals and humans.

Conflict of interest The authors declare that there are no conflicts of interest.

Open Access This article is distributed under the terms of the Creative Commons Attribution 4.0 International License (http:// creativecommons.org/licenses/by/4.0/), which permits unrestricted use, distribution, and reproduction in any medium, provided you give appropriate credit to the original author(s) and the source, provide a link to the Creative Commons license, and indicate if changes were made.

\section{References}

Aksoycan N, Meco O, Ozsan K, Tekeli ME, Sağanak I, Ozuygur B (1983) Enteritisli bir hastadan yurdumuzda ilk defa tesbit edilen Salmonella schleissheim serotipi. [First isolation of a strain of Salmonella schleissheim in Turkey from a patient with enteritis]. Mikrobiyol Bul 17:257-258

Andino A, Hanning I (2015) Salmonella enterica: survival, colonization, and virulence differences among serovars. Sci World J 2015:520179

Bäumler AJ, Tsolis RM, Bowe FA, Kusters JG, Hoffmann S, Heffron F (1996) The pef fimbrial operon of Salmonella Typhimurium mediates adhesion to murine small intestine and is necessary for fluid accumulation in the infant mouse. Infect Immun 64:61-68

Beddoe T, Paton AW, Le Nours J, Rossjohn J, Paton JC (2010) Structure, biological functions and applications of the $\mathrm{AB}_{5}$ toxins. Trends Biochem Sci 35:411-418

Borges KA, Furian TQ, Borsoi A, Moraes HL, Salle CT, Nascimento VP (2013) Detection of virulence-associated genes in Salmonella Enteritidis isolates from chicken in South of Brazil. Pesq Agropec Bras 33:1416-1422

Boyle EC, Bishop JL, Grassl GA, Finlay BB (2007) Salmonella: from pathogenesis to therapeutics. J Bacteriol 189:1489-1495

Briones V, Téllez S, Goyache J, Ballesteros C, Del Pilar Lanzarot M, Domínguez L, Fernández-Garayzábal JF (2004) Salmonella diversity associated with wild reptiles and amphibians in Spain. Environ Microbiol 6:868-871

Cooley MB, Quiñones B, Oryang D, Mandrell RE, Gorski L (2014) Prevalence of Shiga toxin producing Escherichia coli, Salmonella enterica, and Listeria monocytogenes at public access watershed sites in a California Central Coast agricultural region. Front Cell Infect Microbiol 4:30

Dong H, Peng D, Jiao X, Zhang X, Geng S, Liu X (2011) Roles of the spiA gene from Salmonella enteritidis in biofilm formation and virulence. Microbiology 157:1798-1805

Dudek K, Koczura R, Gawałek M, Sajkowska Z, Ekner-Grzyb A (2016) Detection of Salmonella enterica in a sand lizard (Lacerta agilis, Linnaeus, 1758) city population. Herpetol J 26:57-60

Gal-Mor O, Boyle EC, Grass GA (2014) Same species, different diseases: how and why typhoidal and non-typhoidal Salmonella enterica serovars differ. Front Microbiol 5:391

Geue L, Löschner U (2002) Salmonella enterica in reptiles of German and Austrian origin. Vet Microbiol 84:79-91

Giacomodonato MN, Llana MN, Aya Castañeda MDR, Buzzola FR, Sarnacki SH, Cerquetti MC (2014) AvrA effector protein of Salmonella enterica serovar Enteritidis is expressed and translocated in mesenteric lymph nodes at late stages of infection in mice. Microbiology 160:1191-1199

Haag H, Hantke K, Drechsel H, Stojiljkovic I, Jung G, Zähner H (1993) Purification of yersiniabactin: a siderophore and possible virulence factor of Yersinia enterocolitica. J Gen Microbiol 139:2159-2165

Haghjoo E, Galan JE (2004) Salmonella typhi encodes a functional cytolethal distending toxin that is delivered into host cells by a bacterial internalization pathway. Proc Natl Acad Sci USA 101:4614-4619

Hall MLM, Rowe B (1992) Salmonella arizonae in the United Kingdom from 1966 to 1990. Epidemiol Infect 108:59-65

Hernandez J, Bonnedahl J, Waldenström J, Palmgren H, Olsen B (2003) Salmonella in birds migrating through Sweden. Emerg Infect Dis 9:753-755

Hoelzer K, Moreno Switt AI, Wiedmann M (2011) Animal contact as a source of human non-typhoidal salmonellosis. Vet Res 42:34

Huehn S, La Ragione RM, Anjum M, Saunders M, Woodward MJ, Bunge C, Helmuth R, Hauser E, Guerra B, Beutlich J, Brisabois A, Peters T, Svensson L, Madajczak G, Litrup E, Imre A, Herrera-Leon S, Mevius D, Newell DG, Malorny B (2010) Virulotyping and antimicrobial resistance typing of Salmonella enterica serowars relevant to human health in Europe. Foodborne Pathog Dis 7:523-535

Issenhuth-Jeanjean S, Roggentin P, Mikoleit M, Guibourdenche M, de Pinna E, Nair S, Fields PI, Weill FX (2014) Supplement 2008-2010 (no. 48) to the White-Kauffmann-Le Minor scheme. Res Microbiol 165:526-530

Krzymińska S, Koczura R, Mokracka J, Puton T, Kaznowski A (2010) Isolates of the Enterobacter cloacae complex induce apoptosis of human intestinal epithelial cells. Microb Pathog 49:83-89

Lawley TD, Chan K, Thompson LJ, Kim CC, Govoni GR, Monack DM (2006) Genome-wide screen for Salmonella genes required for long-term systemic infection of the mouse. PLoS Pathog 2:e11

López FE, Pescaretti MM, Morero R, Delgado MA (2012) Salmonella Typhimurium general virulence factors: a battle of David against Goliath? Food Res Int 45:842-851

Marcus SL, Brumell JH, Pfeifer CG, Finlay BB (2000) Salmonella pathogenicity islands: big virulence in small packages. Microb Infect 2:145-156 
Morgan E (2007) Salmonella pathogenicity islands. In: Rhen M, Maskell D, Mastroeni P, Threlfal J (eds) Salmonella: molecular biology and pathogenesis. CRC Press, Boca Raton, pp 67-88

Morgan E, Bowen A, Carnell S, Wallis T, Stevens M (2007) SiiE is secreted by the Salmonella enterica serovar Typhimurium pathogenicity island 4-encoded secretion system and contributes to intestinal colonization in cattle. Infect Immun 75:1524-1533

Nawrot R, Wołun-Cholewa M, Białas W, Wyrzykowska D, Balcerkiewicz S, Goździcka-Józefiak A (2010) Cytotoxic activity of proteins isolated from extracts of Corydalis cava tubers in human cervical carcinoma cells. BMC Complement Altern Med 10:78

Palmgren H, McCafferty D, Aspán A, Broman T, Sellin M, Wollin R, Bergström S, Olsen B (2000) Salmonella in subAntarctica: low heterogeneity in salmonella serotypes in South Georgian seals and birds. Epidemiol Infect 125:257-262

Pasmans F, Martel A, Boyen F, Vandekerchove D, Wybo I, Van Immerseel F, Heyndrickx M, Collard JM, Ducatelle R, Haesebrouck F (2005) Characterization of Salmonella isolates from captive lizards. Vet Microbiol 110:285-291

Prager R, Mirold S, Tietze E, Strutz U, Knüppel B, Rabsch W, Hard WD, Tschäpe H (2000) Prevalence and polymorphism of genes encoding translocated effector proteins among clinical isolates of Salmonella enterica. Int J Med Microbiol 290:605-617

PZH and GIS (2016) Infectious diseases and poisonings in Poland in 2015. National Institute of Public Health-PZH/ Chief Sanitary Inspectorate GIS, Warsaw

Raffatellu M, George MD, Akiyama Y, Hornsby MJ, Nuccio SP, Paixao TA, Butler BP, Chu H, Santos RL, Berger T, Berger T, Mak TW, Tsolis RM, Bevins CL, Solnick JV, Dandekar S, Bäumler AJ (2009) Lipocalin-2 resistance confers an advantage to Salmonella enterica serotype Typhimurium for growth and survival in the inflamed intestine. Cell Host Microbe 5:476-486

Reissbrodt R, Rabsch W (1988) Further differentiation of Enterobacteriaceae by means of siderophore-pattern analysis. Zentralbl Bakteriol Mikrobiol Hyg A 268:306-317

Ribble D, Goldstein NB, Norris DA, Shellman YG (2005) A simple technique for quantifying apoptosis in 96-well plates. BMC Biotechnol 5:12

Rytkönen A, Poh J, Garmendia J, Boyle C, Thompson A, Liu M, Freemont P, Hinton JC, Holden DW (2007) SseL, a Salmonella deubiquitinase required for macrophage killing and virulence. Proc Natl Acad Sci USA 104:3502-3507

Sabbagh SC, Forest CG, Lepage C, Leclerc JM, Daigle F (2010) So similar, yet so different: uncovering distinctive features in the genomes of Salmonella enterica serovars Typhimurium and Typhi. FEMS Microbiol Lett 305:1-13

Schubert S, Rakin A, Karch H, Carniel E, Heesemann J (1998) Prevalence of the "high-pathogenicity island" of Yersinia species among Escherichia coli strains that are pathogenic to humans. Infect Immun 66:480-485

Sharma VK, Rohde R, Garg DN, Kumar A (1977) Toads as natural reservoir of Salmonella. Zentralbl Bakteriol Orig A 239:172-177

Skarżyńska M, Hoszowski A, Zając M, Lalak A, Samcik I, Kwit R, Wasyl D (2017) Distribution of Salmonella serovars along the food chain in Poland, 2010-2015. J Vet Res 61:173-179

Skyberg JA, Logue CM, Nolan LK (2006) Virulence genotyping of Salmonella spp. with multiplex PCR. Avian Dis 50:77-81

Streckel W, Wolff AC, Prager R, Tietze E, Tschäpe H (2004) Expression profiles of effector proteins SopB, SopD1, SopE1, and AvrA differ with systemic, enteric, and epidemic strains of Salmonella enterica. Mol Nutr Food Res 48:496-503

Suez J, Porwolllik S, Dagan A, Marzel A, Schorr YI, Desai PT, Agmon V, McClelland M, Rahav G, Gal-Mor O (2013) Virulence gene profiling and pathogenicity characterization of non-typhoidal Salmonella accounted for invasive disease in humans. PLoS ONE 8:e58449

Uzzau S, Brown DJ, Wallis T, Rubino S, Leori G, Bernard S, Casadesus J, Platt DJ, Olsen JE (2000) Host adapted serotypes of Salmonella enterica. Epidemiol Infect 125:229-255

Velge P, Wiedemann A, Rosselin M, Abed N, Boumart Z, Chaussé AM, Grépinet O, Namdari F, Roche SM, Rossignol A, Virlogeux-Payant I (2012) Multiplicity of Salmonella entry mechanisms, a new paradigm for Salmonella pathogenesis. MicrobiologyOpen 1:243-258

Wang H, Paton JC, Herdman BP, Rogers TJ, Beddoe T, Paton AW (2013) The B subunit of an AB5 toxin produced by Salmonella enterica serovar Typhi up-regulates chemokines, cytokines, and adhesion molecules in human macrophage, colonic epithelial, and brain microvascular endothelial cell lines. Infect Immun 81:673-687

Wieczorek K, Osek J (2013) Prevalence and characterisation of Salmonella in slaughtered cattle and beef in Poland. Bull Vet Inst Pulawy 57:607-611

Woodward DL, Khakhria R, Johnson WM (1997) Human salmonellosis associated with exotic pets. J Clin Microbiol 35:2786-2790

Yoon SH, Park YK, Kim JF (2015) PAIDB v2.0: exploration and analysis of pathogenicity and resistance island. D624D630. Nucleic Acids Res 43:D624-D630

Zając M, Wasyl D, Różycki M, Bilska-Zając E, Fafiński Z, Iwaniak W, Krajewska M, Hoszowski A, Konieczna O, Fafińska P, Szulowski K (2016) Free-living snakes as a source and possible vector of Salmonella spp. and parasites. Eur J Wildl Res 62:161-166 